\title{
Introduction: Worlds of Labour Turned Upside Down
}

\author{
Revolutions and Labour Relations in Global Historical Perspective
}

\author{
Pepijn Brandon, Peyman Jafari and Stefan Müller
}

Revolutions are relatively new, rare and extraordinary events in history, which is perhaps one reason why historians and social scientists alike continue to be surprised and fascinated by them. Although this interest goes back to at least the early modern revolutions in England (1640-1660) and the Netherlands (1568-1648), ${ }^{1}$ it was what Eric Hobsbawm calls the "age of revolutions" that inspired the study of the subject in the nineteenth century. The revolutions of this period included the American (1765-1783), the French (1789-1799), the Haitian (1791-1804) and the Irish (1798) revolutions, in addition to the Latin American wars of independence and the revolutions that swept Europe in 1848. ${ }^{2}$ The next upsurge of studies emerged in the second half of the twentieth century, examining the paths of the Russian (1917), German (1918-1919), Chinese (1911 and 1949), Cuban (1953-1959), Hungarian (1956), Portuguese (1974) and Iranian (1979) revolutions. To this list, one should add the anti-colonial revolutions, such as in Algeria (1954-1962), and the revolutions that toppled the Stalinist regimes in 1989 .

During the 1990s, the study of revolutions became confined to specialists, but a number of events in the twenty-first century have put it back under the spotlight. The revolution that toppled Suharto's three-decade rule in Indonesia in 1998 came as a reminder that the end of the twentieth century might not have heralded the end of revolutions. Then came the wave of "colour revolutions" in Eurasia, starting with the overthrow of Slobodan Milošević in Yugoslavia in 2000, and followed by the Rose Revolution in Georgia (2003), the Orange Revolution in Ukraine (2004-2005), the Tulip Revolution in Kyrgyzistan (2005) and the Jeans Revolution in Belarus (2006). ${ }^{3}$ Despite their names, historians and social scientists might find it difficult to define these as revolutions, as they represented regime breakdowns and regime transitions without being

1 Charles Tilly, European revolutions, 1492-1992 (Oxford: Blackwell, 1993).

2 E. J. Hobsbawm, The age of revolution, 1789-1848 (New York: Vintage Books, 1996).

3 Lucan Way, "The real causes of the color revolutions", Journal of Democracy 19, no. 3 (2008); Lincoln Abraham Mitchell, The color revolutions (Philadelphia: University of Pennsylvania Press, 2012). 
accompanied by the long period of social ferment or the structural transformations of political, social and cultural life usually associated with the term. They did, however, revive the debate on the nature of revolution.

A similar impetus came from two other developments. First, in the West, mass movements emerged in the twenty-first century as a reaction to neoliberal globalization, war, austerity politics and environmental degradation. These movements have been far from revolutionary, but they have signalled the return of contentious politics on a mass scale and revitalized political imaginaries of radical social change. ${ }^{4}$ Second, mass uprisings did reach a revolutionary scale in a number of Arab countries in 2011, including Tunisia, Egypt, Bahrain, Yemen, Libya and Syria. These events too, led to a debate about revolution and its changing character in the twenty-first century, as some stressed their revolutionary dynamics, ${ }^{5}$ others their "leaderless" aspect and the role of social media, ${ }^{6}$ while yet others defined them as "refolutions", conceptualizing them as movements that have transcended the historical divide between reform and revolution and combine elements of both. ${ }^{7}$ While the "colour revolutions" of the early zooos seemed to open up the possibility of rethinking revolution as a largely non-violent, but relatively controlled and limited phenomenon, ${ }^{8}$ the Arab Spring and its violent repression seemed to reaffirm more traditional scenarios, in which revolutions comprise several distinct phases of the rise and fall of mass mobilization, intense battles over the political direction of protest, the active dismantling of existing power structures and the threat or actuality of brutal counter-revolution. ${ }^{9}$

Last, a number of anniversaries have fuelled the renewed interest in revolutions. These include the centennial in 2017 of the two Russian revolutions arguably among, if not the most momentous events of the twentieth century and of the German Revolution in 2018. ${ }^{10}$ The same year saw the bicentennial

Paul Mason, Why it's kicking off everywhere: the new global revolutions (London: Verso, 2012). Gilbert Achcar, The people want: a radical exploration of the Arab Uprising (London: Saqi Books, 2013).

6 Michael Hardt and Antonio Negri, "Arabs are democracy's new pioneers", The Guardian, 24 February, 2011.

7 Asef Bayat, Revolution without revolutionaries: making sense of the Arab Spring (Stanford, California: Stanford University Press, 2017).

Julia Gerlach, Color Revolutions in Eurasia (Cham etc.: Springer, 2014).

Brecht De Smet, Gramsci on Tahrir: Revolution and counter-revolution in Egypt (London: Pluto Press, 2016).

See also the fourth edition of Sheila Fitzpatrick, The Russian Revolution (Oxford: Oxford University Press, 2017); Yuri Slezkine, House of Government: A Saga of the Russian Revolution (Princeton: Princeton University Press, 2017); Stephen A. Smith, Russia in Revolution: An Empire in Crisis, 189 o to 1928 (Oxford: Oxford University Press, 2017). With regard to the German Revolution, see Germany 1916-23: A Revolution in Context, ed. Klaus 
of Karl Marx, the most famous theorist and advocate of revolution, followed in 2019 by the fortieth anniversary of the Iranian Revolution. ${ }^{11}$

\section{$1 \quad$ Historiographical Approaches to Revolution}

Along with the ebb and flow of the revolutionary tide, the historiographical and theoretical approaches to revolutions have also changed. As mentioned above, one change concerns the very definition of revolution and the debate about whether particular events can be conceptualized as such. Most historians and social scientists have now shaken off the inclination to measure revolutionary events by the yardstick of the "great" English, French, Russian and Chinese revolutions, and are more prone to understand the modality of revolutions in their changing historical context. As Fred Halliday aptly notes:

Definitions of revolution are, like all definitions in social sciences, conventional: revolutions are not - any more than are nations, classes, even events or dates - objectively given "things" waiting to be unearthed or identified like objects of natural science. They are phenomena which human subjects choose to group, on the basis of criteria of significance and recurrence, into one category rather than another. ${ }^{12}$

It is therefore not surprising that approaches to revolutions have changed when new events have presented themselves as possible candidates and new theoretical and methodological insights have emerged. This has been reflected, for instance, in the endeavours to analyse revolutions as processes rather than as single events in time. With regard to Russia, it is now common for historians to speak not only of the two revolutions of 1917, but to situate them in a revolutionary process running from 1905 to at least the end of the Civil War. ${ }^{13}$ Another change in the study of revolutions has been the shift from a

Weinhauer, Anthony McElligott and Kirsten Heinsohn (Bielefeld: Transcript/Columbia University Press, 2015).

11 See among others the biography on Marx by Gareth Stedman Jones, Karl Marx: Greatness and Illusion (London: Allan Lane, 2016), and the conference "The Iranian Revolution as a World Event", organized at the University of Amsterdam in December 2018.

12 Fred Halliday, Revolution and world politics: the rise and fall of the Sixth Great Power (Houndmills England/Durham, NC: Macmillan Press/Duke University Press, 1999).

13 Laura Engelstein, Russia in Flames: War, Revolution, Civil War, 1914-1921 (Oxford: Oxford University Press, 2018); Mark D. Steinberg, The Russian Revolution 1905-1921 (Oxford: Oxford University Press, 2016). 
narrow focus on their causes, to their dynamics and outcomes. The closer attention paid to the dynamics of mobilization has created the intellectual space to include, in addition to class, the role of other factors such as ideology, organization, repertoires, networks, strategy, leadership, culture, emotions, and gender and ethnic relations. ${ }^{14}$ One of the consequences has been a shift in the treatment of revolutionaries themselves, and of revolutionary ideas such as Marxism. Current historiography tends to treat them less as "organic" expressions or representatives of particular classes, tendencies or interests within the revolutionary process, but also less as the all-powerful shapers of revolutionary events than was once fashionable. ${ }^{15}$ Although such approaches have certainly not disappeared entirely from public narratives on revolution, it is interesting to note that even authors who assign great importance to leaders and their ideologies in the unfolding of revolutionary processes, nowadays tend to approach their actions as a complex outcome of contingencies, dilemmas and influences, rather than as the straightforward application of a "right" or "wrong" set of revolutionary recipes. ${ }^{16}$

The divergent outcome of revolutions has also come under closer scrutiny. ${ }^{17}$ Some of these theoretical and historiographical shifts were well described by one of the eminent scholars of revolutions, Jack Goldstone, who has distinguished four generations in the studies of revolutions. ${ }^{18}$ While the first

14 See for example Charles Tilly and Sidney G. Tarrow, Contentious politics (Boulder, CO: Paradigm Publishers, 2007); Michelle Chase, Revolution within the revolution: women and gender politics in Cuba, 1952-1962 (Chapel Hill: The University of North Carolina Press, 2015); Jean-Pierre Reed, "Emotions in context: Revolutionary accelerators, hope, moral outrage, and other emotions in the making of Nicaragua's revolution", Theory and Society 33, no. 6 (2004); John Foran, Theorizing revolutions (London: Routledge, 1997).

15 While the former approach was of course favoured by many Marxist historians, the latter was very fashionable among Cold War opponents to the very notion of revolution as anything but an ideology-driven scheme devised by minoritarian leaders. For an example of the first approach, see Christopher Hill, Lenin and the Russian Revolution (London: The English Universities Press, 1949), for an example of the second, see Bertram D. Wolfe, Three who made a revolution: A biographical history (New York: The Dial Press, 1948).

16 For example, Tariq Ali, The dilemmas of Lenin: Terrorism, war, empire, love, revolution (London and New York: Verso, 2017).

17 Jack A. Goldstone, "Rethinking revolutions: Integrating origins, processes, and outcomes", Comparative Studies of South Asia, Africa and the Middle East 29, no. 1 (2009); Jeff Carter, Michael Bernhard and Glenn Palmer, "Social revolution, the state, and war: How revolutions affect war-making capacity and interstate war outcomes", Journal of Conflict Resolution 56, no. 3 (2012).

18 Jack A. Goldstone, "Toward a Fourth Generation of Revolutionary Theory", Annual Review of Political Science 4, no. 1 (2001). 
generation of theories about revolutions were mainly descriptive, ${ }^{19}$ the second generation focused on causal factors through various approaches (psychological, structural-functionalist and a combination of both that emphasizes the unevenness caused by rapid modernization). The third generation of revolution theories started to emerge in the 196os and 1970s. They drew intellectual inspiration from a structuralist interpretation of Karl Marx' writings on the mode of production and class struggle, but also on De Tocqueville's views concerning the French Revolution. ${ }^{20}$ The pioneering work of Barrington Moore stressed the changing relations among peasants, the state, landlords and a nascent bourgeoisie during the transition to capitalist agriculture. ${ }^{21} \mathrm{~A}$ decade later, one of Moore's students, Theda Skocpol, modified his structural approach and underpinned it with Weberian notions of state autonomy and multicausality. Following a comparative historical analysis, Skocpol's States and Social Revolutions argues that "social revolutions should be analysed from a structural perspective, with special attention devoted to international contexts and to developments at home and abroad that affect the breakdown of the state organizations of old regimes and the build-up of new, revolutionary state organizations". 22

In reaction to this structuralist turn, and the inadequacies of States and Social Revolutions, which Skocpol conceded in relation to the Iranian Revolution, scholars moved in new directions, calling for greater attention to be paid to the roles of agency, ideology and culture in shaping revolutionary mobilization and objectives, and emphasizing the role of contingency in the course and outcome of revolutions. This ushered in the fourth generation of revolution theories, which has been in the making for the last two decades. In this strand of literature, structural causality is replaced by a more complex understanding in terms of multiple causalities that involve structural and agency-driven factors. As a result, research about revolutions has entered into a dialogue with social

19 See for example Lyford Paterson Edwards, The natural history of revolution (Chicago, IL: The University of Chicago Press, 1927); Clarence Crane Brinton, The anatomy of revolution (New York: W.W. Norton \& Co., 1938); George Sawyer Pettee, The process of revolution: Studies in systematic political science and comparative government, vol. $\mathrm{V}$ (New York: Harper, 1938).

20 Alexis de Tocqueville, The Old Regime and the Revolution, trans. John Bonner (New York: Harper \& Brothers, 1856), http://hdl.loc.gov/loc.gdc/scdooo1.0ooo4399286 [11 November 2019].

21 Barrington Moore, Social origins of dictatorship and democracy: lord and peasant in the making of the modern world (Boston: Beacon Press, 1993 [1966]).

22 Theda Skocpol, States and social revolutions: a comparative analysis of France, Russia and China (Cambridge: Cambridge University Press, 1979), 5 . 
movement studies, which are concerned with similar processes such as mobilization, ideological contestation and confrontation with authorities. ${ }^{23}$ Another development that has had a marked influence on the newer generations of studies of the history of revolutions has been the "global turn", through various trajectories. One of these has been the increasing attention paid to the international context since the late 197os. The international system, for instance, looms large in Theda Skocpol's classic work, States and Social Revolutions. ${ }^{24}$ A more recent trend has postulated an "intersocietal" approach that views the international factors as a constituent part of revolutions. ${ }^{25}$ Others have opted for a transnational approach to revolutions in order to explore the circulation of ideas, people, commodities, practices, etc., as well as the connections between different locations. This approach has produced an impressive body of literature on, for instance, the revolutionary Atlantic in early modern times and studies on particular revolutions from a transnational perspective. ${ }^{26}$

\section{Revolutions and Labour Relations: A Lens to Reconnect Structure and Agency}

A strict division of the theoretical and historiographical approaches to revolutions, such as the four-generational approach, is of course somewhat crude. It would be hard to argue, for example, that attention paid to the complex dynamic between structural processes and collective and individual agency, or to the intricacies of ideology, contingency and revolutionary cultures, are absent from such classical accounts of revolution and counter-revolution as Karl Marx's writings on France in 1848-1851 and 1871, or Leon Trotsky's History of the

23 Goldstone, "Toward a Fourth Generation", 141-142.

24 Skocpol, States and social revolutions.

25 Alexander Anievas and Kamran Matin, Historical Sociology and World History: Uneven and Combined Development Over the Longue Durée (London and New York: Rowman \& Littlefield International, 2016); George Lawson, "Revolutions and the international", Theory and Society 44, no. 4 (2015), 299-319. For an application of this approach in a historical study, see Peyman Jafari, "Oil, labour and revolution: a social history of labour in the Iranian oil industry, 1973-1983" (PhD diss., Leiden University, 2018).

26 Peter Linebaugh and Marcus Rediker, The Many-Headed Hydra:Sailors, Slaves, Commoners and the Hidden History of the Revolutionary Atlantic (Boston: Beacon Press, 2001). See in continuation, Janet Polasky, Revolutions Without Borders: The Call to Liberty in the Atlantic World (New Haven: Yale University Press, 2015); Christian Helm, Botschafter der Revolution: Das transnationale Kommunikationsnetzwerk zwischen der Frente Sandinista de Liberación Nacional und bundesdeutscher Solidaritätsbewegung 1977-1990 (Berlin: De Gruyter, 2018). 
Russian Revolution. ${ }^{27}$ The separation into four generations might also conceal some of the ways in which these older accounts continue to inform present studies. It was a serious engagement with his notorious predecessors that led Charles Tilly, for instance, to develop his own ideas on revolutions, which are difficult to fit into the four described generations. Tilly's analysis of collective action in From Mobilization to Revolution is explicitly linked to the dynamics of capitalism, for which he drew heavily on Marx: "Over the long run, the reorganization of production creates the chief historical actors, the major constellations of interests, the basic threats to those interests, and principal conditions for transfers of power [that is, revolutions]".28 Tilly stresses the importance of interests, organizational resources and opportunity in the conflicts between different groups (states, elites and challengers).

In his later writings, Tilly studied revolutions as specific instances of "contentious politics". Through the works of many scholars, this approach has come to encompass various concepts, such as mobilization structures, political opportunity, framing, protest cycles and repertoires of contention. ${ }^{29}$ From this perspective, a revolution is a specific form of "contentious politics", in which contenders advance exclusive competing claims to control of the state, a significant segment of the population is committed to those claims, and the rulers are unable or unwilling to suppress the contenders. ${ }^{30}$ This definition is inspired by Lenin's classic formulation about revolutionary situations, of course. According to Lenin, such a situation arises under three conditions:

(1) When it is impossible for the ruling classes to maintain their rule without any change; when there is a crisis, in one form or another, among the "upper classes", a crisis in the policy of the ruling class, leading to a fissure through which the discontent and indignation of the oppressed classes burst forth. For a revolution to take place, it is usually insufficient for "the lower classes not to want" to live in the old way; it is also necessary that "the upper classes should be unable" to live in the old way; (2) when the

27 For recent editions of these classical texts in English, Karl Marx, The Political Writings (London and New York: Verso, 2019); Leon Trotsky, History of the Russian Revolution (Chicago: Haymarket Books, 2008).

28 Charles Tilly, From mobilization to revolution (Reading, MA: Addison-Wesley Publishing Co., 1978), 194.

29 Doug McAdam, Political process and the development of Black insurgency, 1930-1970 (Chicago: University of Chicago Press, 1982). Sidney G. Tarrow, Power in movement: social movements, collective action and politics (Cambridge, England and New York: Cambridge University Press, 1994); Tilly and Tarrow, Contentious politics.

Tilly and Tarrow, Contentious politics, 158. 
suffering and want of the oppressed classes have grown more acute than usual; (3) when, as a consequence of the above causes, there is a considerable increase in the activity of the masses ... [who] are drawn both by all the circumstances of the crisis and by the "upper classes" themselves into independent historical action. ${ }^{31}$

For Marxist revolutionaries like Lenin, the core subject of this book - the relationship between revolution and labour relations - might have seemed perfectly self-evident. A strong connection would have been assumed between all three conditions for revolution that he outlined, as well as profound disturbances in the world of labour. In fact, determining the nature of this relationship became central to some of the defining debates between proponents and opponents of a directly revolutionary strategy within the confines of the second, socialist International of that period. The famous controversy over the "breakdown of capitalism", for example, was predicated on the notion that fissures within the ruling class could only have truly revolutionary consequences if they sprang from deep, potentially existential crises within the capitalist mode of production itself. In the same way, Marxist writers and activists of this period tended to take for granted that the self-activity of the working masses during revolution would lead to a transformation of labour relations by, or at least in favour of, these working masses as the logical outcome of revolution. The experience of the twentieth century has cast doubt on the notion of such straightforward connections between revolution and (shifts in) labour relations. The reasons and potential implications for this are discussed at length, and far better than the editors are able to, in the opening essay by Marcel van der Linden. Here, suffice it to say that this doubt concerned each of the times at which a relationship could be traced between labour relations and revolution. At the level of preconditions, for a long period until the very recent return of discussions about the "end of capitalism", to talk about the "impossibility" for the rulers or the ruled to continue living in the old way seemed fanciful, at least in the Western world. At the level of activity, revolutions in which the "independent historical action" of the masses acted as the prime mover of the entire process, not just particular episodes, were the exception rather than the rule. In terms of leadership and ideas, even many of the twentieth-century revolutions carried out under Marxist banners that loudly proclaimed the centrality of the industrial working class, were in practice led by, and infused by

31 V. I. Lenin, "The Collapse of the Second International", cited from the version on the Marxist Internet Archive, https://www.marxists.org/archive/lenin/works/1915/csi/ii.htm [23 August 2019]. 
the desires and prejudices of groups ranging from poor peasants and guerrilla forces to army officers and segments of the existing state apparatus. Lastly, at the level of outcomes, political regimes claiming their basis in revolution, such as those in Eastern Europe or China, more often than not did manage to accomplish changes in labour relations, without fundamentally reducing exploitation, repression and alienation at the point of production or in society as a whole. ${ }^{32}$

The apparent lack of a clear relationship between labour relations and revolution in twentieth-century practice, combined with the deep scepticism of grand narratives and structural explanations beyond the structures of language and imaginations promulgated across fields by the cultural turn, and finally the declining influence of Marxism within academia as well as within actual revolutionary events, all contributed to the marginalization of the "social question" in revolution studies. The essays in this volume, however, are part of reinstating its centrality. The chapters cover a wide range of revolutions of an equally wide range of types: "classical" cases such as the Finnish Revolution of 1918 (an extension of the Russian Revolution) and the Iranian Revolution of 1979, as well as anti-colonial struggles in South America in the nineteenth century and Africa in the twentieth century; revolutions from above (such as the immediate post-war Eastern European experience) as well as revolutions from below (such as the Hungarian Revolution of 1956); near revolutions or "revolutions that did not happen", such as the negotiated transition from Apartheid in South Africa and the East German transition of 1989-199o; and "revolutions within the revolution", such as the workers' uprising against the Bolsheviks in Izhevsk in 1918 or the Cultural Revolution in China. All of them in their own way illustrate that the lack of a straightforward relationship between labour relations and revolution does not signify the lack of any meaningful and enduring relationship between the two. Further, all of them also show how bringing the issue of labour relations to the fore, by necessity involves both questions of structure (from the chokepoints in pre-revolutionary forms of industrial organization to the impact of demography on revolutionary warfare) and agency (from the role of individual militants in single workplaces to the impact of the presence or absence of a revolutionary programme on the possible horizons of the transformation of work).

32 Interestingly, there are significant parallels and overlaps here with the notion of an immediate link between social structures and revolution in another historical timeframe, that of the "Bourgeois Revolution". See Neil Davidson, How revolutionary were the bourgeois revolutions? (Chicago: Haymarket Books, 2012). 
This volume comes out of the 53rd International Conference of Labour and Social History (ITH) that was held in Linz, Austria, in September 2017. The organizers of that conference were of course well aware of the significance of discussing the question of labour relations and revolution on the occasion of the centenary of the Russian Revolution. Nevertheless, as both the proceedings of the conference and this volume that emerged from it show, their inclination from the start was to problematize this relationship rather than to take it for granted. This requires taking on challenging questions. For example, how to explain the apparent mismatch between aims and outcomes in cases such as the Russian Revolution and the revolutions in the (later) satellites, where the "emancipation of labour" was inscribed on revolutionary banners, but the new state soon turned to promoting new forms of (Taylorist) work discipline. When does revolution - in the process of state-led transformations in labour relations - end and when does the central dynamic become one of postrevolutionary consolidation or even counter-revolution? What is the role of larger, perhaps even global cycles of change, such as the one instigated by the eighteenth-century Age of Revolution that saw the spread of both revolutionary and moderate variants of abolitionism, or the global critique of Fordism and Taylorism that emerged around the year 1968? And how do working-class politics during revolutions reflect such wider cycles?

The conference, in the same way as the current volume does, took an expansive view of where to look for connections between labour relations and revolution. Accepting the main thrust of the programme of "Global Labour History" as pursued by the International Institute of Social History in Amsterdam among others, it did not assume that the question of labour's role in revolutionary processes is confined to that of industrial wage workers, or tends to become confined to that of the advance of global capitalism. ${ }^{33}$ For instance, the revolution of the slaves of Saint-Domingue in 1804 has to be seen as a prime example of a directly labour-related upheaval (figuring as the iconic example of so many revolts and attempted revolutions by those bound by commercial slavery). ${ }^{34}$ Equally, the importance of labour relations can also be found in the

33 See among others, Towards a Global History of Domestic and Caregiving Workers, ed. Dirk Hoerder, Elise van Nederveen Meerkerk and Silke Neunsinger (Leiden: Brill, 2015); Karl Heinz Roth (ed.), On the Road to Global Labour History. A Festschrift for Marcel van der Linden (Leiden: Brill, 2017).

34 For the huge amount of literature on Saint Domingue/Haiti, see Paul Cheney, Cul de Sac: Patrimony, Capitalism, and Slavery in French Saint-Domingue (Chicago: University Press, 2017). 
Arab Spring, including both the rising level of militancy of traditional groups of industrial workers in countries such as Egypt in the course of the 200os, and the struggles of informal or precarious labourers and those working in civil service jobs. ${ }^{35}$

Given the origins of the volume and the timing of the conference from which it sprang, it might appear strange that the Russian Revolution itself is only featured through two events at its periphery. Exploring the possibilities of reintroducing labour relations as a key factor in the study of revolutions, requires in our view a relatively broad approach to both what constitutes a revolution and to what counts as a connection between revolutions and labour relations. In selecting the chapters for this volume, we have not restricted ourselves to those "classical" cases in which revolutions demonstrably comprised the entire gamut of a deep social crisis preceding the revolution, sustained mass involvement during the revolution, and large scale social changes as an outcome of the revolution. For example, the French Revolution of the eighteenth century with its deep impact on landed property and rural social relations, the Haitian Revolution that abolished slavery or the Russian Revolution as seen from the factory. Focusing on those events would certainly have created the opportunity to re-envision one particular mode of the relationship between political and social revolution. The limits of such an enterprise, however, are made clear by Van der Linden's introductory essay. A far greater number of revolutions and semi-revolutions in the twentieth century and beyond include some elements, but not all. By including discussions of a wide-ranging selection of successful and unsuccessful attempts to challenge existing political regimes, and by including connections with changes in labour relations - both at a very profound and at a more limited level - the volume suggests the many ways in which a focus on labour relations can bridge questions of structure and agency in revolutionary processes. This wide selection of cases also means that the volume is less concerned with The Social Revolution than it is with instances of the social in revolutions.

The chapters that follow Van der Linden's introductory essay are not primarily theoretical or historiographical in nature, but present particular revolutions for which rigorous study of class dynamics is combined with attention paid to one or more aspects of the relationship between political events and labour relations highlighted above. Rather than summing up the content of each of the chapters here in the same order, we will let them speak for themselves and 
merely stress the findings in them that are most surprising or challenging for the overall theme of the volume. Gabriel Di Meglio discusses the relationship of popular classes, revolution and labour relations in the Argentine war of independence during the first decades of the nineteenth century. It is remarkable that although the Argentine War of Independence would not frequently figure in a general overview of labour-relations driven revolutions, in fact Di Meglio's overview of the revolution most explicitly deals with the "classical" question of the role of contending social classes in political upheaval. However, as he shows, support for the revolution and support for emancipation from oppressive labour relations were not at all aligned in a simple or direct way. In fact, he stresses that it was often the Argentine elites who pushed for the transformation of labour relations in order to exploit economic opportunities for the new state in the making. The labourers on the other hand could sometimes use this for their own interests, as was the case with slaves who used the army as a road to emancipation, but more often people were opposed to these changes due to the detrimental effects they had on their living conditions and autonomy.

In the case of Argentina, therefore, revolutionary war was connected quite centrally to transformations in labour relations, but this was to an important extent a vector of the activity of employers, not just the workers, who sometimes resisted. The activity of workers with the aim of changing labour relations in their own favour is represented most explicitly in the two chapters that deal with events immediately following the 1917 revolution. Although there is ample literature showing the role of workers in that revolutionary year, the two chapters shift the focus to a very different location. In a highly engaging chapter written originally in Russian by Dmitriy Churakov, and translated and reworked for the purpose of this volume, the author deals with the largest revolt of industrial workers against the Bolsheviks, which took place in Izhevsk in the summer of 1918. The chapter describes in great detail how workers responded to the contradiction between the high hopes created by the revolution and the dire circumstances that the new regime soon found itself in. Workers were certainly not the passive instruments in a power struggle between Bolsheviks, oppositional socialists and the Whites. Instead, as Churakov shows, their disenchantment was the real cause of the temporary loss of power by the Bolsheviks in Izhevsk, but ironically for very similar reasons to the defeat of their adversaries that followed. Tiina Lintunen and Kimmo Elo also focus on workers fighting in the frontlines of a revolution, this time in Finland, which up to 1918 had been part of the Russian Empire. Their chapter is particularly important for highlighting the role of networks of committed socialist women, inside and outside the workforce, in recruiting the "workforce of revolution" 
itself, namely the women working mostly behind the frontlines of the red battalions. Interestingly, although the sources for this chapter originate from the trials in the aftermath of a bloody civil war, Lintunen and Elo manage to bring out how strongly the creation of the red army's female component relied on pre-revolutionary everyday organizing, and how much supporting the labour of revolution during the civil war consisted of mundane tasks, sometimes performed out of high ideals and sometimes just as a job.

While acknowledging that the working class is not limited to industrial workers in factories, and therefore that labour-related struggles have many venues outside the main industrial centres, most chapters in this volume still focus on precisely that social setting. Even in the chapter by Lintunen and Elo, which focuses more on family relations, the shape of these networks was still in large part moulded by factory work and trade union activity. However, in their chapter on the Portuguese Carnation Revolution of 1974-1975, Raquel Varela and João Carlos Louçã consciously shift away from this terrain. They argue that the revolution started not in the Lisbon of the early 1970s, but in the Portuguese colonies of the 196os. Instead of treating the history of the Portuguese Revolution on the one hand and the anti-colonial wars on the other hand as separate, the authors emphasize an entanglement that went deeper than simply the fact that defeat overseas led to demoralization in the army. Varela and Louçã pay much attention to forced labour as one of the core grievances leading to prolonged contestation against the regime. With their question about the impact of resistance against coerced labour on the revolutionary movement, they widen the historiographical perspective on Portuguese and colonial history.

Partly as a result of the centrality of the Eastern European experience in rethinking the history of socialism, workers and revolution, and partly due to the more contingent reason that historically, Iтн has brought together historical researchers from across the Iron Curtain, the complicated legacy of state socialism when trying to connect labour relations and revolutions features very prominently in this volume. Adrian Grama opens his essay with what perhaps is the fundamental question in this respect: "How might the experience of East European workers between 1945 and 1989 fit into a general history of the left in the twentieth century?" His own contribution to answering this question is a wide overview of the conflicting tendencies in Eastern European labour management, which included both substantial autonomy for skilled workers in the production process and the use of wage incentives as a means of subjecting them to the rationale of centralized plans. His nuanced reading of the conflicts arising out of the particular forms of organizing industrial work under Eastern European state socialism connect remarkably well with the detailed case study presented in the chapter by Zsombor Bódy. In his chapter on the Hungarian 
Revolution of 1956, Bódy analyses the events in a single Hungarian plant before, during and after the revolution: the Ikarus bus factory. He examines the conflicts that escalated in the plant during the revolution from the perspective of the careers of the main leaders of the Ikarus workers' council and the tensions between different groups among the workers, technical employees and managers of the enterprise. Bódy concludes that the conflicts that came to the fore during the revolution grew in part out of earlier tensions between the management and the workforce, the potential and limits of the production technology in use, and the work culture (and Eigensinn) of the skilled labourers and engineers.

Felix Wemheuer's lively sketch of the massive changes in labour relations in China during the Maoist epoch shed light on another communist country, but also a country that was still in the grip of semi-colonial conditions. Wemheuer deals with a historical experience that included transformations in the world of work at a scale that no other case study in this volume comes close to. The sevenfold rise of the workforce in state enterprises alone gives an impression of the social mobility that was intended, but that was also feared by the Communist Party for its potentially destabilizing effects. The resulting rifts led to the mass mobilizations and strikes of the late 196os and early 1970s, accompanying the so-called Cultural Revolution. Wemheuer argues (against the dominant narrative) that the rebellion of temporary workers was to some extent a success, and that the workers were not merely an instrument of the Party's left-wing faction. In that respect, the Chinese dynamics differed markedly from those of Eastern European labour policies before 1989.

All the chapters that deal with state socialism have to grapple with the contradictions of the regimes' ideological claims to represent working-class interests, or even workers' power, and the starkly different realities of workers' disenfranchisement in the factories. However, that such contradictions are not entirely unique to socialist regimes is shown by Peyman Jafari in his chapter on the Iranian Revolution. Jafari traces the history of the rise and fall of the Showras (workers' councils in the oil industry) as an organizational expression of workers' influence on the political conjecture opened by the fall of the Shah. At one level, this seems to represent a somewhat traditional example of workers' self-activity as a revolutionary force, and its defeat at the hands of a counterrevolution in the form of the consolidation of the Islamic state. However, this account is given greater depth by Jafari's multi-level treatment of the complicated relationship between different tendencies within the Islamic state and the workers, which often included claims about both overlapping and conflicting interests between the oil workers and the state.

In general, the chapters described so far illustrate the difficulty in strictly separating phases of revolution, post-revolutionary consolidation and even 
counter-revolution, which in many historical examples has been dressed up as an extension and deepening of the very processes that in practice were cut short or derailed by them. In his chapter, Knud Andresen adds a further layer to this, by asking whether the developments in South Africa can be described as a negotiated revolution. Andresen examines the relations between trade unions and multinational companies in the process of dismantling Apartheid. He argues that as a result of the internal and external crisis of the regime, the exclusion of black workers gradually became an economic problem, and demands for reforms were made by these multinational employers. In parallel with this process, non-racist trade unions emerged and their negotiating position grew significantly. Andresen posits that in a similar way to many other revolutions, change in South Africa was not reached simply by the activity of the most suppressed or desperate groups of workers, but that a very large role was played by those groups of workers who, because of their position of strength, managed to achieve some social gains, but at the same time remained excluded from power.

While Andresen's chapter deals with a situation in which the factors favouring revolutionary action by workers were strongly present, but were channelled into a more negotiated trajectory of change, Renate Hürtgen's chapter illustrates a case of political revolution in which the potential for the working class to enter the revolutionary stage in an organized and independent form remained largely latent. Focusing on the experience of workers' self-organization in the 1989-1990 revolutionary transition in the GDR, she highlights the organization and demands of workers' committees in the German Wende, in which the language of class was sidelined as belonging to the old regime. Thus, the analysed independent shop floor initiatives were not successful and did not survive beyond a brief period in the autumn and winter of 1989-1990. So strong was the process of reframing workers' demands of this period into the safe, non-revolutionary direction of a longing for more consumer choice and of their organization into the structures of West German trade unionism, that all memory of workers' activity during this period has largely faded.

The final point, drawn from Hürtgen's contribution, raises an important issue for all the chapters in this volume. Workers' self-activity as a driving force of revolution, and as potentially the most powerful challenger of prevailing social conditions, has historically been repressed in a double way. The first is in the actual history of revolution, either by direct defeat at the hand of counterrevolution or through a more complicated and mediated process in which post-revolutionary regimes create new oppressive labour relations or resurrect old ones. The second is in writing the history of revolution, in which the agency of workers - waged or otherwise - is often belittled or denied. The aim of 
this volume is to contribute to the resurrection of the notion that labour relations, and the struggles that swirled around them, are crucial in understanding the phenomenon of revolution in all its complexity.

\section{Acknowledgements}

This volume came about as the result of the 53rd International Conference of Labour and Social History (ITH) which took place in Linz, Austria on 21-23 September 2017. In producing this volume we received generous support, financial and in other forms, from IT H's coordinators, the Friedrich Ebert Stiftung, and the International Institute of Social History. Several people extended a helping hand during the process of editing this collection of essays. Our special gratitude goes to Igor Batista, Aad Blok, Marcel van der Linden, Johanna Lübke, David Mayer, Lukas Neissl, and last but not least Susan Zimmermann, as well as the editors and staff at Brill.

\section{Bibliography}

Achcar, Gilbert, The people want: a radical exploration of the Arab Uprising (London: Saqi Books, 2013).

Ali, Tariq, The dilemmas of Lenin: Terrorism, war, empire, love, revolution (London and New York: Verso, 2017).

Anievas, Alexander, and Kamran Matin, Historical Sociology and World History: Uneven and Combined Development Over the Longue Durée (London and New York: Rowman \& Littlefield International, 2016).

Bayat, Asef, Revolution without revolutionaries: making sense of the Arab Spring (Stanford, California: Stanford University Press, 2017).

Beinin, Joel, and Frédéric Vairel, Social Movements, Mobilization, and Contestation in the Middle East and North Africa (Stanford, CA: Stanford University Press, 2011).

Brinton, Clarence Crane, The anatomy of revolution (New York: W.W. Norton \& Co., 1938).

Carter, Jeff, Michael Bernhard, and Glenn Palmer, "Social revolution, the state, and war: How revolutions affect war-making capacity and interstate war outcomes", Journal of Conflict Resolution 56, no. 3 (2012), 439-466.

Chase, Michelle, Revolution within the revolution: women and gender politics in Cuba, 1952-1962 (Chapel Hill: The University of North Carolina Press, 2015).

Cheney, Paul, Cul de Sac: Patrimony, Capitalism, and Slavery in French Saint-Domingue (Chicago: University Press, 2017). 
Davidson, Neil, How revolutionary were the bourgeois revolutions? (Chicago: Haymarket Books, 2012).

Engelstein, Laura, Russia in Flames: War, Revolution, Civil War, 1914-1921 (Oxford: Oxford University Press, 2018).

Edwards, Lyford Paterson, The natural history of revolution (Chicago, IL: The University of Chicago Press, 1927).

Fitzpatrick, Sheila, The Russian Revolution (Oxford: Oxford University Press, 2017).

Foran, John, Theorizing revolutions (London: Routledge, 1997).

Gerlach, Julia, Color Revolutions in Eurasia (Cham etc.: Springer, 2014).

Goldstone, Jack A., "Toward a Fourth Generation of Revolutionary Theory”, Annual Review of Political Science 4, no. 1 (2001), 139-187.

Goldstone, Jack A., "Rethinking revolutions: Integrating origins, processes, and outcomes", Comparative Studies of South Asia, Africa and the Middle East 29, no. 1 (2009), 18-32.

Halliday, Fred, Revolution and world politics: the rise and fall of the Sixth Great Power (Houndmills England/Durham, NC: Macmillan Press/Duke University Press, 1999).

Hardt, Michael, and Antonio Negri, “Arabs are democracy's new pioneers", The Guardian, 24 February, 2011.

Helm, Christian, Botschafter der Revolution:Das transnationale Kommunikationsnetzwerk zwischen der Frente Sandinista de Liberación Nacional und bundesdeutscher Solidaritätsbewegung 1977-199o (Berlin: De Gruyter, 2018).

Hill, Christopher, Lenin and the Russian Revolution (London: The English Universities Press, 1949).

Hobsbawm, E. J., The age of revolution, 1789-1848 (New York: Vintage Books, 1996).

Hoerder, Dirk, Elise van Nederveen Meerkerk, and Silke Neunsinger, ed., Towards a Global History of Domestic and Caregiving Workers (Leiden: Brill, 2015).

Jafari, Peyman, "Oil, labour and revolution: a social history of labour in the Iranian oil industry, 1973-1983" (PhD diss., Leiden University, 2018).

Jones, Gareth Stedman, Karl Marx: Greatness and Illusion (London: Allan Lane, 2016).

Linebaugh, Peter, and Marcus Rediker, The Many-Headed Hydra:Sailors, Slaves, Commoners and the Hidden History of the Revolutionary Atlantic (Boston: Beacon Press, 2001).

Lawson, George, "Revolutions and the international", Theory and Society 44, no. 4 (2015), 299-319.

Marx, Karl, The Political Writings (London and New York: Verso, 2019).

Mason, Paul, Why it's kicking off everywhere: the new global revolutions (London: Verso, 2012).

McAdam, Doug, Political process and the development of Black insurgency, 1930-1970 (Chicago: University of Chicago Press, 1982).

Mitchell, Lincoln Abraham, The color revolutions (Philadelphia: University of Pennsylvania Press, 2012). 
Moore, Barrington, Social origins of dictatorship and democracy: lord and peasant in the making of the modern world (Boston: Beacon Press, 1993 [1966]).

Pettee, George Sawyer, The process of revolution: Studies in systematic political science and comparative government, vol. $v$ (New York: Harper, 1938).

Polasky, Janet, Revolutions Without Borders: The Call to Liberty in the Atlantic World (New Haven: Yale University Press, 2015).

Reed, Jean-Pierre, "Emotions in context: Revolutionary accelerators, hope, moral outrage, and other emotions in the making of Nicaragua's revolution", Theory and Society 33 , no. 6 (2004), 653-673.

Skocpol, Theda, States and social revolutions: a comparative analysis of France, Russia and China (Cambridge: Cambridge University Press, 1979).

Smet, Brecht De, Gramsci on Tahrir: Revolution and counter-revolution in Egypt (London: Pluto Press, 2016).

Smith, Stephen A., Russia in Revolution: An Empire in Crisis, 1890 to 1928 (Oxford: Oxford University Press, 2017).

Steinberg, Mark D., The Russian Revolution 1905-1921 (Oxford: Oxford University Press, 2016).

Roth, Karl Heinz, ed., On the Road to Global Labour History. A Festschrift for Marcel van der Linden (Leiden: Brill, 2017).

Tarrow, Sidney G., Power in movement: social movements, collective action and politics (Cambridge, England and New York: Cambridge University Press, 1994).

Tilly, Charles, From mobilization to revolution (Reading, MA: Addison-Wesley Publishing Co., 1978).

Tilly, Charles, European revolutions, 1492-1992 (Oxford: Blackwell, 1993).

Tilly, Charles, and Sidney G. Tarrow, Contentious politics (Boulder, CO: Paradigm Publishers, 2007).

Tocqueville, Alexis de, The Old Regime and the Revolution, trans. John Bonner (New York: Harper \& Brothers, 1856).

Trotsky, Leon, History of the Russian Revolution (Chicago: Haymarket Books, 2008).

Way, Lucan, "The real causes of the color revolutions", Journal of Democracy 19, no. 3 (2008), 55-69.

Weinhauer, Klaus, Anthony McElligott, and Kirsten Heinsohn, ed., Germany 1916-23: A Revolution in Context (Bielefeld: Transcript/Columbia University Press, 2015).

Wolfe, Bertram D., Three who made a revolution: A biographical history (New York: The Dial Press, 1948).

Yuri Slezkine, House of Government: A Saga of the Russian Revolution (Princeton: Princeton University Press, 2017). 